\title{
Paradigm Transformation and Practical Innovation of Information Literacy Education in Applied University in China
}

\author{
Yuan LUO \\ Wuchang Shouyi University, Wuhan, China
}

\begin{abstract}
Keywords: Information Literacy Education; Outcome-Based Education; Framework for Information Literacy for Higher Education; Critical Thinking; Lifelong Learning Ability.
\end{abstract}

\begin{abstract}
Framework for Information Literacy for Higher Education issued by Association of College and Research Libraries (ACRL Framework) is a guiding document for university libraries to carry out the work of information literacy education. "Outcome-Based Education" (OBE) is an international professional talent training model and certification system in which the whole education system is driven by undergraduate outcome quality. Through in-depth study of OBE educational model and ACRL Framework, this article tries to find common ground and joint point in professional talent training as the theoretical foundations for education reform of information literacy. Meanwhile, by practical exploration, the author thinks and summarizes the changing trends of information literacy education in higher education goals, teaching structure and teaching methods, the model of "information literacy education embedded in the whole process of undergraduate talent training" is formed, so as to provide reference for similar universities.
\end{abstract}

\section{Introduction}

With the rapid development of information technology, information literacy has become the necessary ability literacy for people to adapt to the modern society. UNESCO held two thematic world conferences in 2003 and 2005 respectively and issued the Prague Declaration and Alexander Declaration [1]. It is pointed out that information literacy is the precondition for people to survive in the information society as well as the core element of lifelong learning. As the information center and teaching service unit, university library plays the role of education in improving college students' information literacy. Through the investigation on the status of information literacy education in applied universities in China, the author finds that most libraries still take the traditional information retrieval course as the main form of education, which is not closely connected with the professional courses. Information literacy education is lack of systematic planning for curriculum design. Single teaching model is carried out. Teaching content is relatively obsolete. The classroom is still teacher-centered and the learners are not highly engaged and interactive. Various phenomena indicate that the education model of traditional information literacy can no longer meet the demands of the rapidly changing information environment on talent cultivation. The reform and innovation of information literacy education in colleges and universities are imperative.

Through literature research, this paper tries to find the common ground and combination point of Framework for Information Literacy for Higher Education issued by ACRL (hereinafter referred to as the ACRL Framework) and Outcome-Based Education (OBE) model in professional talent training as the theoretical basis for reforming information literacy education. Through empirical research, the author finds and summarizes the changing trends of information literacy education in training goals, teaching structure and teaching methods, the model of "information literacy education embedded in the whole process of undergraduate talent training" is formed, so as to provide reference for similar universities.

\section{Outcome-Based Education (OBE)}

Outcome-Based Education (OBE) was derived from fundamental education reforms in the United States and Australia [2]. It is a structural model to organize, implement and evaluate education based 
on the expected learning output. The fundamental transformation of education paradigm from "content oriented" to "student-oriented" is realized. The teaching objective precedes the teaching content; all teaching activities revolve around students' ability performance at graduation. Students become the center of teaching activities. The OBE education model is considered as an innovation of education paradigm [3].

"Learning outcome" is also the basis of credit conversion and mutual recognition in international higher education, as well as the cornerstone of internationalization and talent flow of higher education. Currently, most of the member states of the Washington Agreement adopt "outcome-based" certification standards. In China, some universities have tried to reform teaching under the guidance of OBE concept around the main line of "defining the expected learning outcome - realizing the expected learning outcome - evaluating learning outcome", the evaluation of student outcome constitutes the closed loop of continuous improvement of education quality [3].

In defining the expected learning outcomes, Wuchang Shouyi University, where the author works, as an application-oriented university, studied the outcome evaluation standards: the science, engineering and technology disciplines refer to the Engineering Education Certification Standard issued by China Engineering Education Professional Certification Association (revised in March 2015); the humanities and social sciences disciplines refer to the General Standards for Undergraduate Professional Certification (revised in November 2015) mapped out by department of education evaluation center of China's Ministry of Education. Both criteria include the indicator point of "self-learning and lifelong learning ability", that is to master the self-learning method through effective means and to have the ability to keep learning and adapt to social development. The cornerstone and core element of it are information literacy.

\section{ACRL Framework}

For decades, Association of College and Research Libraries (ACRL) has played a leading role in promoting information literacy in higher education. ACRL Framework issued in Feb. 2015 is the latest guiding document for university library to carry out the work of information literacy education. It contains six core "threshold" concepts for university libraries to flexibly implement [4].

In general teaching direction, it guides information literacy education to develop by integrating with the discipline and specialty education. In teaching design, it encourages librarians to cooperate fully with teachers, departments or school curriculum committees to plan information literacy courses as a whole [5]. It pays attention to the gradual and systematic cultivation of information literacy of learners in the whole learning process. In teaching content, compared with the Information Literacy Competency Standards for Higher Education issued by ACRL in 2000 [6], it adds new contents such as "research as inquiry", "scholarship as conversation", "authority is constructed and contextual", etc. It extends and focuses the education target to the training of core competencies like inquiry learning, teamwork, communication, critical thinking, which are the necessary literacy for college students to adapt to the modern society and realize self-development. In implementation strategy, it is suggested to coordinate closely with the school's overall educational objectives and development strategy.

\section{Theoretical Findings of OBE Education and ACRL Framework}

Common goal: OBE education and ACRL framework share the same education goal, namely "to improve the information literacy and lifelong learning ability of college students". "Lifelong learning ability", as an indicator of talent export requirements under the OBE education model, is often ignored in the traditional teaching mode of "content-based". Our university once conducted a survey on the job performance of our graduates. Employers reported that the two weakest points for graduates were their ability to think and solve problems independently and their ability to communicate with others and express themselves. To some extent, it reflects the graduates' lack of information literacy and lifelong learning ability. Looking review at our existing curriculum system, there is a lack of support for the points. At this time, library information literacy courses aiming at 
improving information literacy and lifelong learning ability should take responsibility and make contributions.

Same Concept: OBE and ACRL Framework share the same idea: "cooperation" and "integration". "Integration" means that information literacy education should be properly integrated into different stages of talents training. It should run through every link of undergraduate education. As the implementation opinion of ACRL framework states, information literacy needs to be integrated into the academic activities of students at different stages in a gradual and systematic way. "Cooperation" is embodied in the cooperation between the library and various departments of the school, seeking the policy support of the teaching department in charge. "Cooperation" is also embodied in the cooperation between teachers and librarians to achieve the goal of integrating education content of information literacy with subject knowledge, thus promoting the cultivation of self-learning and lifelong learning ability.

Focus Issue: OBE and ACRL Framework focus on the same issues: how to cultivate students' comprehensive qualities such as inquiry learning, communication and expression, critical thinking, etc. All these are the core competence necessary for college students to adapt to modern society and realize self-development. It is the basis of self-learning and lifelong learning. It is also the core training target of library information literacy education.

Model Construction and Education IntrospectBased on the above theoretical research and findings, our library tried hard to reform the traditional education paradigm and built an education framework and model of "information literacy education embedded in the whole process of undergraduate talent training" which is "student-oriented", as shown in figure 1:

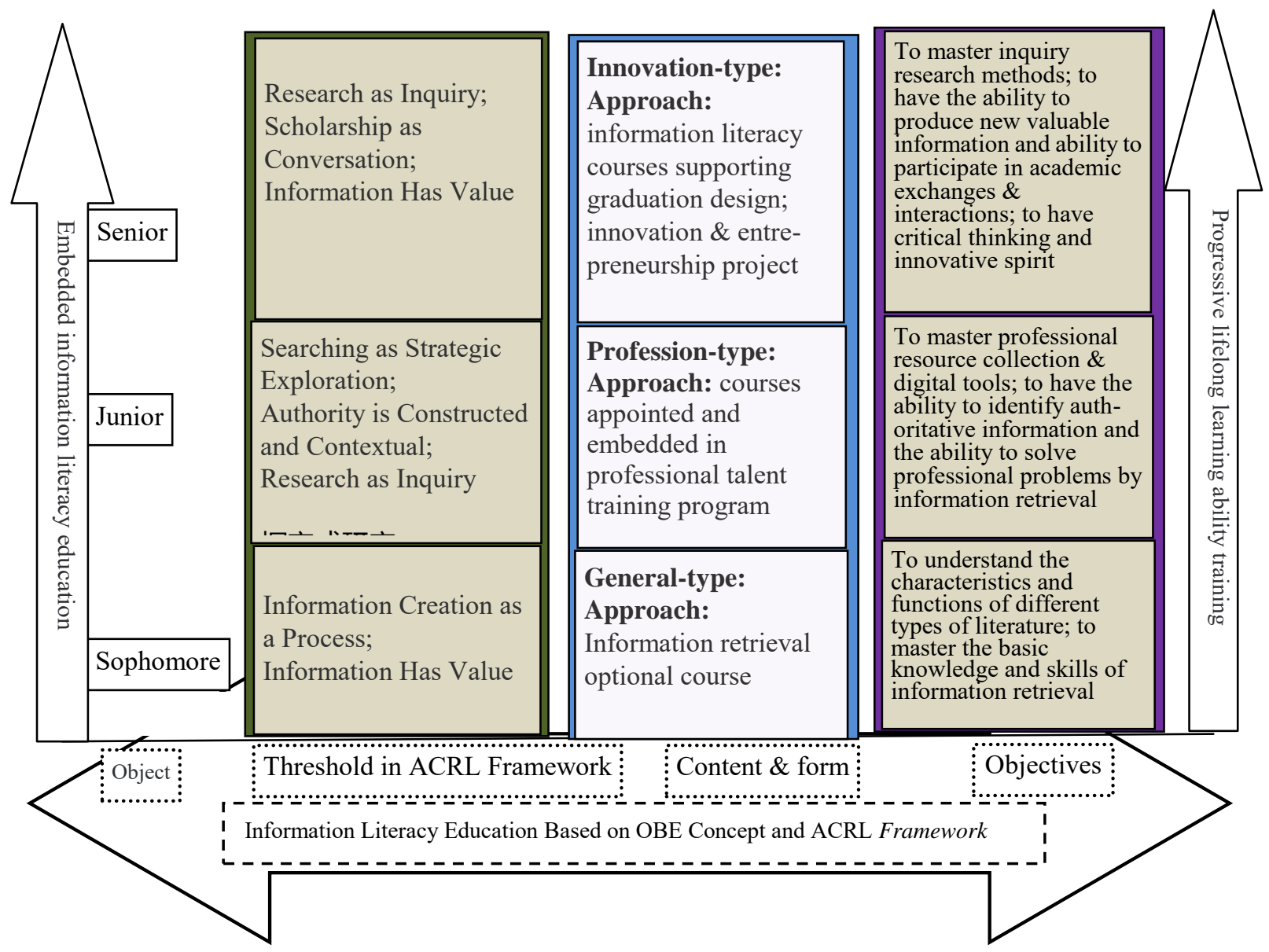

Figure 1. New education model

In the innovative practice of information literacy education, our library introspected and verified the breakthrough and innovation of the new model in the process of "pre-set question" to "answer question". 


\section{How does the new model reflect the overall view and education hierarchy?}

As shown in the figure 1, the new model takes the whole process of undergraduate education as the perspective, considering the different information needs of students in the course of 4 years, the information literacy education is timely given. The disadvantage of focusing only on a single education project in the traditional mode is abandoned. The typical three-stage training framework pays attention to the periodical cultivation of information literacy of learners in the whole learning process and lifelong learning, which reflects the characteristics of infiltration, progressive and systematization.

\section{How does the new model embody the concept of cooperation and integration?}

In traditional mode, information literacy education is regarded as an independent course in isolation from professional learning. While, taking professional requirements as the clue, the resources are refined, analyzed and systematized to form a disciplinary resource system; the new model is closely connected with learners' professional learning and practical activities. By deep cooperation of librarian and teacher, subject information resources and their acquisition methods are acquired by embedding professional cases or specific tasks, cultivate students' ability to apply retrieval knowledge to solve complex professional problems, which is practiced. "Cooperation" and "integration" are also reflected in the deep cooperation between the library and various departments of the school. Library information literacy education has got the policy support of school red headed documents. Five professional information literacy courses (16 hours / 1 credit) have been included in the professional talent training plan.

\section{How to acquire inquiry learning, conversational research and communication skills?}

Inquiry learning, conversational research, communication skills and teamwork spirit are the new training goals proposed in the ACRL Framework [4]. They are also the basic elements of information literacy. The traditional model pays more attention to retrieval skills while the new model focuses on the improvement of learning ability and comprehensive literacy. In new model, after the theory, practice and application modules, the teaching link of "team presentation" (personal performance and contribution account for $30 \%$ of the final score) is added. As a team, students work together to complete a retrieval project, make PPT, select team representative and present the project analysis, search process and search results. In this way, students are expected to master the working thought and method of solving practical problems based on information retrieval. New model motivates learners to adopt conversational research, independent inquiry learning to cultivate self-learning, lifelong learning and innovation ability as well as to promote communication skills, teamwork spirits and critical thinking to meet the demand of social market for professional talents.

\section{How is critical thinking taught?}

Critical thinking is the ability to evaluate, compare, analyze, judge and synthesize information. To determine whether an assertion is true, it is important to collect evidence in support of or against the assertion and to evaluate the quality of the evidence [7]. There are courses on critical thinking in the curricula of many universities in Europe and the United States. Many universities even require it as a compulsory course. Some western scholars have recently argued that a single course in critical thinking was not enough to improve one's critical thinking. Only by adding the element of critical thinking in each course can students improve their critical thinking ability [8]. How can we promote the development of students' thinking mode in information literacy course? We need to change the traditional teacher-lecturing model. Situation construction, problem inspiration and self-reflection are the effective methods we should take in the class to develop critical thinking [9]. By finding solutions to well-designed questions, students' independent thinking is motivated, by successfully solving problem, students will have got the sense of achievement in academic study. 


\section{Conclusion}

Many university libraries at home and abroad are developing towards "teaching library". More and more attention has been paid to the quality-oriented education and learning ability of students. Library service has been involved in the academic and scientific career of teachers and students. The quality of libraries has begun to be judged by the role they play in the success of their users. Guided by ACRL Framework, combined with our university's "Outcome-Based Education" model reform, this paper tries to build an information literacy education frame and model with the characteristics of infiltration, progressive and systematization to match school's final objectives of professional talents cultivation, to enable our graduate students to have the discipline literacy, independent learning and lifelong learning ability required by the international professional certification system.

\section{Acknowledgement}

This research was financially supported by the 2016 Research Fund Program of Hubei Academic Library Committee: Research on education model of information literacy based on the whole process of undergraduate talent training (Program Number: 2016-ZDX-04).

\section{References}

[1] Information on http://www.unesco.org/new/fileadmin/MULTIMEDIA/HQ/CI/CI/pdf/PragueDe claration.pdf

[2] Information on https://en.wikipedia.org/wiki/Outcome-based_education

[3] Peihua Gu, Wenlong Hu, Peng Lin. Engineering Education Model Based on "Outcome-Based Education" - Shantou University's Practice and Exploration [J]. Higher Engineering Education Research, 2014 (1): 27-37. (in Chinese)

[4] Information on http://www.ala.org/acrl/standards/ilframework

[5] Lifeng Han, Qian Wang, Jin Li. Framework for Information Literacy for Higher Education [J]. Journal of Academic Libraries, 2015 (6): 111-113. (in Chinese)

[6] Information on https://alair.ala.org/bitstream/handle/11213/7668/ACRL\%20Information\%20Lit eracy $\% 20$ Competency $\% 20$ Standards $\% 20$ for $\% 20$ Higher $\% 20$ Education.pdf?sequence $=1 \&$ is Allowed $=\mathrm{y}$

[7] (America) Dennis Coon, translated by Gang Zheng. Introduction to psychology: the way of thinking and behavior (9th edition) [M]. China Light Industry Press, 2004, 3 (1): 39.

[8] Xiao-Dong Yue. Formation and cultivation of critical thinking: The practice and enlightenment of western modern education [J]. Education Research, 2000 (08): 65-69. (in Chinese)

[9] Ya-ping $\mathrm{Hu}, \mathrm{Ru}$ Bai. American information training course system and enlightenment based on critical thinking [J]. Library and Information Service, 2014, 58 (18): 83-88. 